\title{
Quaderni
}

QUADERN I Communication, technologies, pouvoir

76 | Automne 2011

Les promesses de la biodiversité

\section{The rise of the idea of biodiversity: crises, responses and expertise}

\section{Libby Robin}

\section{(2) OpenEdition}

\section{Journals}

\section{Electronic version}

URL: http://journals.openedition.org/quaderni/92

DOI: 10.4000/quaderni.92

ISSN: 2105-2956

\section{Publisher}

Les éditions de la Maison des sciences de l'Homme

\section{Printed version}

Date of publication: 1 September 2011

Number of pages: 25-37

\section{Electronic reference}

Libby Robin, "The rise of the idea of biodiversity: crises, responses and expertise », Quaderni [Online], 76 | Automne 2011, Online since 01 September 2014, connection on 30 April 2019. URL : http:// journals.openedition.org/quaderni/92 ; DOI : 10.4000/quaderni.92 


\section{$D$ ossier}

\section{the rise of Background}

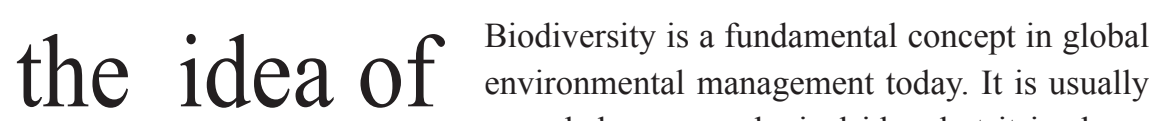
regarded as an ecological idea, but it is also a biodiversity : crises, responses and expertise

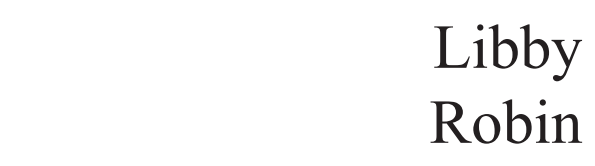

Australian National University, Canberra / Royal Institute of Technology (KTH), Stockholm political idea and a tool for managing non-human nature. A series of historical crises have reshaped the way the western world considers, defines and manages biodiversity. This paper uses the methods of cultural history to analyse the emergence of biodiversity as a driver and shaper of policies and international conservation conventions, particularly where the conventions are responding to alarm or crisis.

'Biodiversity' here includes species diversity, genetic diversity and ecosystem diversity, as defined by the peak expert group, the International Union for the Conservation of Nature (IUCN) (Farnham 2007: 2). The IUCN, originally founded in 1948, claims to be the world's first 'global environmental organization'. Its international headquarters are in Gland, Switzerland. Sponsored by the United Nations, IUCN now describes itself as a democratic network that connects over 1,000 government and non-government organisations (IUCN 2011). It is a major authority on biodiversity. 'Species richness (the number of species in a given area) represents a single but important metric that is valuable as the common currency of the diversity of life', its website states, but it also considers genetic diversity and ecosystem diversity as part of its brief.

The central argument of this paper is that a crisis itself frames its own solution. Responding to a crisis depends on the understanding of the underlying problem. This understanding also identifies 
appropriate 'expert' problem-solvers. Thus it is helpful to consider the historical construction of environmental crisis in parallel with the development of scientific ideas about biodiversity, and the role the concept of biodiversity might play in any solution to the environmental crisis. It is also useful follow the history of the particular expertise that is called on for specific crises in different eras.

Biological diversity is a construct of the discipline of biology, usually ecology, genetics or evolutionary biology. A response to environmental crisis, however, is not necessarily scientific. It is just as likely to be political, or provided by a management or policy framework. Thus biodiversity may be simultaneously both a scientific and a social tool, and a key concept for science, management and governance. Any drive to plan an environmental future (or to 'solve' the crisis) draws on basic science, but it also depends on practical action and ways to measure response to, or outcomes from, that action.

\section{Biodiversity as the Measure of Environmental Crisis}

Biodiversity is more than a 'new name for nature' (Farnham 2007:2). It provides a way to measure change in nature, human-induced and otherwise. Biologists quantify species, measure genetic variation and consider the pressures on the health of whole ecosystems. The goal of conservation is a healthy ecosystem. How this may be achieved demands a variety of specialist expertise and a good measure of political will. Managers and scientists agree that more biologically diverse systems are more complex and therefore better able to withstand shock and change (Holling
1973). Ecosystem health and biodiversity are therefore seen to be mutually supportive.

Biodiversity is a framework for understanding both 'the phenomenon of life' and the impact the activities of humans put on it. While the term biodiversity carries a veneer of scientific independence, its emergence as a 'buzzword' in the 1980s was because of its usefulness in environmental activist circles: it became more than a mere measure of nature: it became a moral entreaty to respond to the 'environmental crisis' that was understood and defined in terms of loss of natural variety. (Farnham 2007).

The idea of biological diversity could be seen to the earliest ideas about ordering and classifying nature, if not Aristotelian world views, then at least back to the $18^{\text {th }}$ century Swedish natural philosopher, Carl von Linné, whose Systema natura $(1753,1758)$ still shapes the binomial classifications system used to name plants and animals throughout the world. The European vision of enlightenment science provided the dominant narrative for nomenclature, for naming and differentiating the species we count when we talk about 'biodiversity'.

The next major step was to make biological diversity urgent, rather than merely descriptive. A new sub-discipline, conservation biology, emerged in the 1980s, which founder Michael Soulé (1985) dubbed a 'science of crisis'. In this moment of crisis, the media-friendly term 'biodiversity' emerged. Thomas Lovejoy and Edward O. Wilson have both been claimed as the originator of the term biodiversity (Farnham 2007; Wilson 1992): it was a word of the 1980s environmen- 
tal crisis. Biological diversity had been used as a political concept before: for example, it was used in parliament in defence of wild country in the Little Desert, in Australia in 1969. (Robin 1998). But biodiversity had a grand 'international moment' when the ecological crisis met politics in the United States, and its applications became increasingly global, with funding from national governments, international lobby groups and non-government organisations.

The environmental crisis about threatened species and their habitats brought policy and ecology together. The future of the biota depended on politics and people, ecologists realised: they were no longer documenting species in the wild, but rather performing triage under emergency conditions and bigger scales than ever before. The crisis that Soulé (1985) identified demanded concerted action on more than just local and regional scales: this was emergency management for the planet.

Farnham documented the rise of the term 'biological diversity' in the Institute for Scientific Information database. It hardly appeared at all in the early 1980s. There were, he noted, zero references to biodiversity in 1980 and 1981 and just 7 in 1982 , but by the $21^{\text {st }}$ century there were thousands - over 4,000 references in 2004 (Farnham 2007: 1-3). The database is grounded in only North American data and it only counts 'scientific information', but Farnham's analysis reflects the rapid rise in international currency of the term biodiversity (or biological diversity) in just three decades.

When 'experts' like Wilson coin the term biodiversity, and then the term shapes defines the understanding of 'the environmental crisis', there is some basis for David Takacs's strong assertion that biodiversity became a 'tool for a zealous defense of a particular social construction of nature' in the 1980s. This term was undoubtedly a claim for power by conservation biologists (Takacs 1996: 1-2). But if we are to understand the full international implications, and to get beyond the narrowly North American frame adopted by Farnham, Takacs and the self-proclaimed biodiversity experts themselves, it is helpful to historicise and internationalise the nature of the environmental crisis itself and step outside the white hot politics of the 1980s. While there is a dominant narrative that argues that biodiversity emerged in the 1980s with 'the' environmental crisis, there are clearly earlier environmental crises, where ideas of biological diversity also played a part. These offer perspective on how the 1980s 'moment' emerged, and allow us to move on from it and consider where the idea of biodiversity has travelled since.

\section{Environmental crises and ecology for mana- gement}

There were a series of environmental crises in the western world that shaped the relations between ecological science, natural resource management and environmental politics in the half-century between the 1930s and the 1980s. Here, I consider just three of these, in roughly chronological order: desertification, the national parks movement and environmental health.

\section{The crisis of desertification}

The dramatic dust storms of the American midwest in 1935 darkened the skies of New York and 
signalled the devastation of agricultural crops. Ecologist, Paul Sears' Deserts on the March was written during these storms, all about the limits of the land and his science. 'We have been deceived by the glib statement that science has given man control over nature... We do not and cannot manipulate nature from the outside. We must work our will by knowing laws and conforming to them, never forgetting that we are a part of that upon which we work.'(Sears 1949: 167). The establishment of the US Soil Conservation Service in 1935 was emblematic of crisis-framed management thinking in this period (Wilkening 2011).

Desertification is the crisis that drives a 'land ethic', promoted by Sears (1949) and more prominently by Aldo Leopold (1949). In the later edition of Deserts on the March, Sears went beyond soil conservation. He called for an integration of conservation and natural resources: rather than pressing 'for a solution of an individual problem'. He also considered the 'common pattern of relationships' between renewable natural resources argued for conserving the whole, including the people (Sears 1949: 165-6).

Dust storms also struck the mallee country of south eastern Australia in the summer of 1934-35. They were part of decades of dust storms that had darkened the skies of the cities and even reddened the snowfields of New Zealand. Some dust storms blew as early as the 1890 s, but the 'dirty thirties' Dust Bowl of the United States provided additional impetus and a model for government response. The Council for Scientific and Industrial Research (CSIR) sent ecologist Francis Ratcliffe out to the affected areas to report on the problem of 'sand drift' that year. He concluded that pastoral development needed to be more attuned with the limits of the arid country (Ratcliffe 1949). Soil conservation authorities were established soon after these storms in New South Wales (1938) and Victoria (1940). Ratcliffe, like Sears, had a wider readership than just scientists. His popular book Flying Fox and Drifting Sand reflected on the limits of both his science and the outback regions of Australia for the pastoral enterprise. Such limits of the land were most keenly felt in post-industrial settlements, where agricultural and industrial revolutions were simultaneous as in Australia and the mid-west United States. Sears commented that 'mechanical invention plus exuberant vitality have accomplished the conquest of a continent with unparalleled speed', but the cost of breaking nature's rules is too high (Sears 1949: 10).

In 1951, the United Nations launched an international program in Arid Zone Research (Robin 2007: 112-13). It aimed to halt 'desertification', advocating science to restore ecological health to lands needed for food and fibre, particularly in Israel and India, the new post-war nations with extensive tracts of arid land. Soil conservation was an important element of this work, a branch of which later became 'restoration ecology'.

\section{National Parks: Saving nature and national identity}

Wilderness was an important part of national identity in the United States, most prominently expressed in the idea of a National Park as a place 'free from human interference' (Nash 1982). From the 1960s onwards, the national 
park concept was part of a series of international events. Beginning with the first World Conference of National Parks, held in Seattle in 1962, the National Park idea, present in a number of places (including Australia, New Zealand, Canada and Sweden) since before World War I, was refined to become more explicitly focused on the protection of biological diversity through the exclusion of people. National Parks were sometimes lauded as "America's Best Idea", a rhetoric that still continues in some circles (Public Lands History Center 2011). John Muir, founder in 1892 of the Sierra Club, was regarded as the 'father of wilderness thinking' and an American hero. In 1970, the year of Earth Day, an event often touted by US writers as the 'dawn of the environmental revolution' (eg Nash 1982), the United States Congress voted a large sum in support of a World Centennial of National Parks to celebrate the foundation of Yellowstone National Park. This Centennial cemented America's nationalist National Parks Idea into international consciousness. The moral claim to the world's first national park lent authority to the American model for conservation and biodiversity management. The model suited scientific national parks managers in a range of places including Canada, Australia and New Zealand. Canadian, J.G. Nelson, for example, in 1978 advocated that 'ideally a national park contains few signs of man' (Nelson et al 1978: 5). In a place without humans, an expertise in nature is sufficient. This view of national parks was criticised within a decade.

\section{Biomagnification and human health}

Rachel Carson's best-selling book, Silent Spring was published in 1962, the year of the first World
Conference of National Parks. The spring without birdsong heralded another, more sinister environmental 'cause', the pollution of the world by excessive use of industrial pesticides. Carson's manifesto suggested the connection between loss of biological diversity and human health, and how this could occur quickly over a few short generations. Pesticides polluted the environment, then were 'biomagnified' as they moved up the food chain and down the generations. The idea of biomagnification lent weight to the idea of understanding whole ecosystems and how they worked: the pesticide that killed the 'pest' animal also killed its predator, and as it moved up the food chain became increasingly dangerous to 'top predators', including humans. It was a powerful image, and a powerful way to popularise a crucial insight of ecosystem ecology. Such pollution could not be confined within national borders, and quickly became an issue of international concern. This crisis authorised both ecosystem expertise and international diplomacy throughout the western world, where chemical pesticides were widespread.

\section{Big ecology: Global scales and international collaborations}

Other global initiatives were a foot in ecological science, supported by concerns about biological diversity and the emerging computer technologies. The International Biological Program (IBP) (1960s-70s) brought together another way to consider the world's biodiversity through 'ecosystem science'. (Coleman 2010). In an important recent book, Big Ecology, Daniel Coleman considers the history of the institutional framework, particularly America's National 
Science Foundation (NSF) that bankrolled global Big Science projects in biology modelled on the successful International Geophysical Year (1957-58) in Earth sciences. IBP was the first of the NSF's programs. Long-Term Ecological Research (LTER) followed in the 1980s, and in the present NSF supports a National Ecological Observatory Network (NEON) (which has a more national and less global scope than IBP).

IBP marked the emergence of widespread mathematical modelling in ecology that reshaped the ecosystem concept (as defined by Tansley in 1935), taking it beyond local and regional applications to comparative international and even planetary scales (Golley 1993). Frank Golley, another scientist who reflected historically on this era, was a director of research in NSF. 'Ecosystem science' was, in his terms, the most important framework for setting up large-scale and global research programs, and NSF funding followed this principle. His own training in the energetics of the food chain came from Eugene P. Odum, with whom he worked at the University of Georgia. The Odum connection directly shaped the NSF's thinking, and Odum's Principles of Ecology textbook, first published in 1953, and still being revised in 2005 (Coleman 2010), was an internationally important tool in the training of professional ecologists and in framing ecological 'expertise' from the 1950s onwards.

The great success of IBP, in Golley's view, was not its capacity to meet the goals that were set by its original organisers, but rather the fact that it led to the institutional structures that supported permanent ecosystem studies through the NSF. (Golley 1993: 2) Reading the history of ideas alongside the history of power gives us a space to look at the national and the global together. It reveals how the global aspirations of IBP in the 1970s had narrowed to national lobbying for funds in the 1980s. While the IBP had a truly global aspiration, this was actually achieved by competition between nations to be at the "table of ongoing research" as Coleman called it.

The outcome of re-nationalising the biodiversity enterprise in the 1980 s resulted in renewed efforts in the United States and its nationally strategic neighbours (for example, South and Central America), rather than a global approach. Major conservation biology journals reflected nationalist biases, even into the new millennium, not least because of research funding arrangements. A major survey of these journals at the turn of the millennium revealed that biodiversity research tends to be undertaken in the country of the author. It also revealed that most authors came from first-world countries, and most often biological survey-focus is in national parks and protected areas in those first-world countries. Thus most of the work to protect species and ecological communities is being done in the places where biodiversity in a planetary sense is least threatened (Fazey et al. 2005a; 2005b). These literature surveys were alarming for a planet where typically global threats are to biota in developing world economies, and in places not protected by biodiversity legislation.

\section{Beyond just governments}

Meanwhile a global agenda that considered biological diversity and human development together in places that included Africa, Asia and 
Oceania, was increasingly being pursued in other ways, especially via international organisations such as the IUCN. The growth of the not-forprofit sector in conservation biology follows the trajectory of the rising popularity of the idea of biodiversity. The IUCN's benchmarks and its Convention for Biodiversity, drafted for Rio in 1992, and enforced since 29 December 1993, drive government natural resource management policy in 160 countries. But its own organisation is a union of over 1,000 government and nongovernment organisation (NGO) members with democratic voting rights. In 2011, it also has 11,000 'volunteer scientists' working in more than 160 countries. They are not just volunteers. They are also scientists.

Sometimes environmental managers too, are scientists, but they must grapple with the social and human dimensions of preserving the non-human biota that are beyond their scientific expertise. As one Australian natural resource manager, R.A. Kenchington, put it: 'We do not manage the environment, only the human behaviours that affect its structure and processes' (Kenchington 1994). The 1980s reinvention of the idea of biodiversity changed ecological science and redefined the expertise required to achieve its aims. It also embedded biodiversity and extinctions into broader management imperatives. The IUCN and other international environmental organisations with scientific roots have had to grow new branches to provide policy for managers and to motivate different sorts of political action.

Extinction is a powerful motivator for political action and public fundraising. Even as the idea of biodiversity gathered pace in the scientific lite- rature of the 1980s, it was being operationalized differently by the state and international groups such as the United Nations, and by environmental activists and non-government organisations (NGOs). From the mid-1980s, the idea of biodiversity is redefined through concepts such as Threatened Species, Megadiversity and Invasion Biology, which are dynamic responses to crisis and prescriptive of action. These carry a moral import to engage with change and to acknowledge the role of human activities in altering nature.

\section{Threatened species}

The IUCN published The Red List of Threatened Species in 1986 at the 'science of crisis' moment in conservation biology. This was not the first list of endangered species to be published by IUCN, but it was marketed in a different way. The Red List was not just a list, but also Red, the colour of alarm. It aimed to represent a crisis that could shift policy and politics. The Red List provided a baseline for global assessments of the conservation status of species. It is regularly updated and scientific, but also practical, in keeping with the IUCN's international codes of 'best practice' for managing biodiversity and key statistical summaries. For example, from a recent Red List we know that between 1500 and 2009, 875 extinctions have been documented. In this endeavour, the IUCN enabled a model for reporting on the success of 'public private partnerships' that go beyond governments and international diplomacy.

\section{Megadiversity}

Conservation International (CI) is a non-profit organisation established in 1987, headquartered in 
Arlington, Virginia, near Washington DC, USA. CI claims to be part of the shift from conservation as 'preserving natural areas as untouched relics of the past'. Instead, 'it envision[s] conservation as a working model of the future' (CI 2011). In particular, CI urges the reconnection of people and nature. Its mission is 'to protect the health of humanity by protecting Earth's ecosystems and biodiversity'. One of its important decisions was to declare a 'Group of 17 Megadiversity countries'. These countries harbour more than two thirds of the planet's biological wealth. This was an economic practicality: it was a way of justifying the spending strategies of the limited conservation dollar. Strikingly, of the 17 countries, only Australia and the United States have first world economies and western traditions of management. Thus this concept has driven CI to prioritise money and effort into 'megadiverse' places that have not had the benefit of local scientific biodiversity expertise.

\section{Invasion Biology}

Invasion biology is the science that responds to 'threats' to biodiversity. It is an example of a symbiosis between the technical experts and the enthusiastic volunteers for biodiversity. Its origins came from the 1950 s, particularly a book by ecologist Charles Elton, Ecology of invasions by animals and plants (1958), which started as a popular radio program before it became a book. Mark Davis comments that biological invasions have received more attention in recent years 'both from ecologists and the public-at-large than any other ecological topic' except climate change. (Davis 2009: 1) His account of the discipline (of invasion biology) is an expert's account of the 'approaches, findings, controversies and conclusions in the field', not a report on invasive species. It is highly reflective on the mutuality of practical conservation and the trajectory of the discipline.

\section{Understanding Global Change in the Anthro- pocene}

In the late $18^{\text {th }}$ century, as the industrial revolution gathered pace, we entered a new geological era, the Anthropocene, where the activities of the human species came to affect all aspects of our biophysical environment (Crutzen 2002; Robin and Steffen 2007). Since the 1950s, sometimes termed the Great Acceleration, global change has magnified further, and markedly. The power of our species over nature on an evolutionary scale, suggests a precautionary principle in our consideration of planetary futures, and the setting of 'planetary limits' (Rockström et al 2009). Three concepts are crucial to setting such limits: resilience, social-ecological systems and an environmental justice that recognises that the western scientific framework has disproportionately affected ecological systems at the expense of the less industrialised traditions.

\section{Resilience}

Resilience was a key concept in shifting ecosystem thinking from science into management in the 1970s. Holling (1973: 14) defined the notion of resilience as a 'measure of the persistence of systems and their ability to absorb change and disturbance' while maintaining their systemic structure. The Odum generation of ecologists worked with whole ecosystems, rather than focusing on single elements, and linked not 
just biological, but also physical environments. The physiology of the animal was nested in a cycle that depended on plants, soils, climate and other abiotic factors, and converted these physical elements into energy. In the same period, increasingly mathematical representations (for example, predator-prey curves) became the basis for modelling and created a hierarchy of elements of the ecosystem. But the focus on 'persistence': it was not about maximizing either efficiency or a particular reward, but one which maintains 'flexibility above all else.' (Holling 1973: 18). This was a strategy for times of uncertainty. Instead of a focus on predicting futures, managers of natural resources should rather maximize the range of possible futures, given the complexity of the system under unknown future conditions (Walker and Salt 2006).

\section{Social-ecological systems}

The task of management demands balancing scientific ideals with economically viable and socially just outcomes. Scientifically-directed conservation philosophy, with a focus on pure nature 'captured' much of the biodiversity conservation agenda from the 1960 s to the $1980 \mathrm{~s}$. More recently, however, social communities are now included along with ecological, and integrated as social-ecological systems (SES). 'Biodiversity' is thus a more complex concept as it embraces the people alongside nature. It demands expertise in social systems, as well as natural systems. Resilience of the whole social-ecological system is a fully integrated idea: it describes how landscapes and communities can absorb disturbance and maintain their function in a changing world. (Walker and Salt, 2006) As biodiversity has be- come part of the global economy (through such concepts as 'ecological services') it is now embedded in 'triple bottom line' accounting systems: society, economy and ecology are all weighted together, in the rhetoric of sustainability since the Brundtland Report (UNWCED 1987).

\section{Environmental justice}

Is it still true that 'Biodiversity is a whitefella word', as one 1990s bumper sticker declared? Prominent Aboriginal professor Marcia Langton was one of many Indigenous Australian thinkers in the 1990s who argued that the institutions of biodiversity bypassed local Indigenous knowledge. US Journalist Mark Dowie reported tensions building between indigenous peoples, who felt themselves to be conservation refugees, and biodiversity activists. One indigenous activist said that 'while extractive industries were still a serious threat to their welfare and cultural integrity, their new and biggest enemy was "conservation", (Dowie 2005: 18). The black-list of 'culturewrecking institutions' (keeping company with Shell, Texaco etc.) included CI and the IUCN itself. These BINGOs (Big International NonGovernment Organisations) 'wrecked cultures' by adopting a 'one-size-fits-all' approach to biodiversity conservation (Dowie 2005).

Anthropologist Paige West noted that WWF (established in 1961 as the World Wide Fund for Nature) spends more in New Guinea than their national government's whole environment budget, making them disproportionately influential (West 2006). She found the WWF biologists based at the Crater Mountain reserve, while they helped her with her work, seldom listened to her expertise 
as a field anthropologist or to the expertise of the local people, as she suggested ways to include local people's knowledge into the conservation initiative. West did not suggest that indigenous peoples are better ecologists than western scientists, but like Langton, she was concerned that western scientific institutions are a form of cultural invasion. Cultural displacements for conservation are not new. For example, in 1969, the Makuleke people were forcibly removed from their land to expand the Kruger National Park (Carruthers 1997). But as conservation urgency has become more global, people displaced are increasingly distant from those who govern biodiversity decisions. The poorest people often depend on 'wild' or under-developed nature, and conservation priorities must accommodate livelihoods for vulnerable people.

\section{The Sixth Mass Extinction}

Since life began on Earth, five major mass extinctions and several minor events have led to large and sudden drops in biodiversity. We have perhaps entered the 'sixth mass extinction', the first anthropogenic extinction event, this one being caused by avoidable human behaviour. It is the biggest crisis for biodiversity ever - and it is 'unnatural'. The roots of the 'ecologic crisis' (as Lynn White Jr called it in 1967) are based in deeply-held cultural beliefs and in the culture of science itself. Threats to the diversity of life on earth have been accelerating since the onset in the industrial revolution.

Following the Millennium Assessment, the IUCN is now working on an economic assessment of the value of biodiversity (TEEB, the Economics of Ecosystems and Biodiversity) as part of the IPBES (International Platform on Biodiversity and Ecosystem Services) (IUCN 2011). This sort of assessment brings biodiversity into line with economic assessments more familiar to western governments and large corporations, and endorses a new expertise of ecological economics. The drive to price ecological services has the potential to integrate ecological ideas and international markets (Daily 1997).

If ecosystems shift in response to climate change, the boundaries of national parks and protected areas may no longer contain the habitats for threatened species. The world outside parks, the 'matrix', is increasingly important to biodiversity (Lindenmayer \& Fischer 2006). Ecologists and conservationists now work together to connect lands through whole-landscape planning, something that has long been successful in densely populated places like England and Wales, where national parks have never excluded people. Australia is a wealthy place, where megadiversity underpins both the economy and national identity and science is highly respected (Robin 2007). Nonetheless, biodiversity is in decline everywhere from the pressure of threats such as habitat loss and invasive species (Steffen et al. 2009). Australia still leads the world in small mammal extinctions. Ecologists find that increasingly their work is in 'climate change adaptation'. While funding for climate change science is increasing, that for invasive species eradication, an important focus for specialist biodiversity scientists since the 1980s, has declined markedly.

Global change has many facets, all of which 
interact: there is no 'one size fits all' approach to biodiversity conservation that works even within politically stable first economies, let alone in rapidly developing countries where economic imperatives overwhelm planning, and in war zones without civil order. In the new millennium, as we come to the end of yet another 'hottest decade in planetary history', biodiversity is just one of many aspects of concern. The idea of 'expertise for biodiversity' is becoming more diffuse.

International NGOs like CI still focus on Biodiversity, but it is number six in the initiatives on their website, behind Climate, Freshwater, Food, Health and Cultural Services. Global change has brought a demand for new expertise. Biodiversity experts still have a place at the big global table of 'global change science', but the fundamental methods and purposes of science itself are shifting under this pressure. Sheila Jasanoff's 'social technologies of humility' that 'give combined attention to substance and process, and stress deliberation as well as analysis' (Jasanoff 2003: 243) are needed to complement traditional scientific expertise. Ecology is a necessary, but no longer sufficient, expertise for biodiversity in the crisis of the sixth mass extinction.

\section{$R \cdot \dot{E} \cdot F \cdot \dot{E} \cdot R \cdot E \cdot N \cdot C \cdot E \cdot S$}

CARRUTHERS, Jane. 1997. 'Nationhood and national parks' in Ecology and Empire. Ed. Griffiths T. \& Robin L. Edinburgh: Keele UP: 125-38. CARSON, R. 1962. Silent Spring NY: Houghton Mifflin.

CI 2011 - website: http:/www.conservation.org/ COLEMAN, D. C. 2010. Big Ecology. Berkeley, U Cal. Press.

CRUTZEN, P.J. 2002. 'Geology of Mankind', Nature, 415: 23.

DAILY, G.C. 1997. Nature's Services. Washington: Island Press.

DAVIS M.A. 2009. Invasion Biology. Oxford: OUP.

DOWIE, M. 2005. 'Conservation Refugees' Orion Magazine (Nov-Dec) 16-27.

FARNHAM, T. 2007. Saving Nature's Legacy: The Origins of the Idea of Biodiversity, New Haven: Yale UP.

FAZEY, I. et al. 2005a. Who does all the research in conservation biology? Biodiversity and Conservation 14: 917-934.

FAZEY I. et al. 2005b. 'What do conservation biologists publish?' Biological Conservation 124: 63-73.

GOLLEY, F.B. 1993. History of the Ecosystem Concept in Ecology. New Haven: Yale UP.

HOLLING, C.S. 1973. 'Resilience and stability in ecological systems', Ann. Rev. Ecol. System. $4: 1-23$.

IUCN website 2011: http://www.iucn.org/about/ JASANOFF, S. 2003, 'Technologies of humility', Minerva 41: 233-44.

KENCHINGTON, R.A. 1994., 'Conservation and Coastal Zone Management', In Conservation 
Biology in Australia, [Ed. Moritz, C. \& Kikkawa J.] Sydney: Surrey Beatty.

LINDENMAYER, D. B. and Fischer J. 2006. Habitat Fragmentation and Landscape Change, Melbourne: CSIRO Publishing.

NASH, Roderick 1982. Wilderness and the American Mind. $3^{\text {rd }}$ ed. (first ed. 1967), New Haven: Yale UP.

NELSON, J.G. et al. 1978. International Experience with National Parks, Ontario: Geography, Univ. Waterloo.

ODUM, Eugene P. 1953. Fundamentals of Ecology, Philadelphia: Saunders.

PUBLIC LANDS HISTORY CENTER (Univ. Colorado) 2011. National Parks Beyond the Nation: http://nationalparksbeyondthenation. wordpress.com/ .

ROBIN, L. 1997. 'Ecology: A Science of Empire?' In Griffiths and Robin: 63-75.

ROBIN, L. 1998. Defending the Little Desert, Carlton: Melbourne UP.

ROBIN, L. 2007. How a Continent Created a Nation, Sydney: UNSW Press.

ROBIN, L. and Steffen W. 2007. 'History for the Anthropocene', History Compass, 5(5): 1694-1719.

ROCKSTRÖM, J et al. 2009. A safe operating space for humanity. Nature 461, 472-475.

SEARS, P. 1949. Deserts on the March. [1 $1^{\text {st }} \mathrm{ed}$. 1935] London: Routledge.

SOULÉ, M.E. 1985. 'What is Conservation Biology?', Bioscience, 35(11), December, 727.

STEFFEN, W. et al. 2009. Australia's Biodiversity and Climate Change. Melbourne: CSIRO Publishing.

TAKACS, D. The Idea of Biodiversity: Philosophies of Paradise. Baltimore: Johns Hopkins UP. WALKER, B. and Salt D. 2006. Resilience Think- ing Washington: Island Press.

WEST, Paige 2006. Conservation is our Government Now, Durham: Duke UP.

WILSON, E.O. 1992. The Diversity of Life, Camb. Mass.: Harvard UP.

WILKENING, K. 2011. 'Intercontinental transport of dust', Environment and History 17(2): 313-39.

UNWCED 1987 Our Common Future (Brundtland Report), Oxford: OUP.
Key words: biodiversity, ecosystem, Big Ecology, resilience, IBP, IUCN, CI, environmental justice. 


\section{$\mathrm{R} \cdot \mathrm{E} \cdot \mathrm{S} \cdot \mathrm{U} \cdot \mathrm{M} \cdot \mathrm{E}$}

The idea of biodiversity has often changed or developed in response to crisis or alarm. New developments seemingly control the crisis, and they also entrench particular expertise. This paper presents a historical view of the development of biodiversity and conservation biology, the 'science of crisis'. Biodiversity has developed from crises in science, practical management challenges and political activism, and all contribute to shaping the concept as it plays out in global change science in the $21^{\text {st }}$ century. Ecology, the 'fundamental' science underpinning the concept, is a necessary, but not a sufficient expertise for understanding and managing the planet's biodiversity in the era of the Anthropocene. 
